After $48 \mathrm{~h}$ of treatment a significant decline in bicarbonate levels (from 35,3 \pm 4,7 to $31,1 \pm 3,9 \mathrm{mmol} / \mathrm{L}, \mathrm{p}<0,001$ ), $\mathrm{pH}$ (from $7,45 \pm 0,05$ to $7,41 \pm 0,06, \mathrm{p}<0,001$ ), and PCO2 (from $52.9 \pm 10$ to $51,2 \pm 10 \mathrm{mmHg}, \mathrm{p}=0,002$ ) were found, whereas anion GAP increased (from 6,8 \pm 9,8 to $8,7 \pm 3,8, \mathrm{p}$ $=0,001)$. Mechanical ventilation was in use in 102 patients, (31,6\% were extubated during acetazolamide treatment).

Average Acetazolamide dose was $8,46 \mathrm{mg} / \mathrm{Kg} / \mathrm{day}$. None of the patients suffered from serious side-effects attributable to Acetazolamide.

Conclusions Acetazolamide treatment improved metabolic alkalosis secondary to diuretic treatment in critically ill children, contributing to a decrease in $\mathrm{PaCO} 2$. Enteral administration was effective and well tolerated without serious adverse effects.

\section{PS-244a IS VITAMIN D DEFICIENCY A RISK FACTOR FOR URINARY TRACT INFECTION IN CHILDREN?}

${ }^{1} \mathrm{M}$ Tekin, ${ }^{1} \mathrm{C}$ Konca, ${ }^{1} \mathrm{~V}$ Celik, ${ }^{1} \mathrm{H}$ Almis, ${ }^{2} \mathrm{Z}$ Kahramaner, ${ }^{2} \mathrm{~A}$ Erdemir, ${ }^{3} \mathrm{~A}$ Gulyuz, ${ }^{4} \mathrm{~F}$ Uckardes, ${ }^{1} \mathrm{M}$ Turgut. ${ }^{1}$ Pediatrics, Adiyaman University School of Medicine, Adiyaman, Turkey; ${ }^{2}$ Pediatrics Neonatology Clinic, Adiyaman University School of Medicine, Adiyaman, Turkey; ${ }^{3}$ Pediatrics, Sevgi Hospital, Malatya, Turkey; ${ }^{4}$ Statistics, Adiyaman University School of Medicine, Adiyaman, Turkey

\subsection{6/archdischild-2014-307384.543}

Background and aims There is increasing evidence that vitamin D deficiency plays an important role in susceptibility to infections. We aimed to examine whether there is any association between serum levels of 25-hydroxy vitamin D (25(OH)D3) and urinary tract infections (UTI) among children.

Methods Serum calcium (Ca), phosphorus (P), alkaline phosphatase (ALP), parathormone (PTH) and serum 25(OH)D3 levels were measured in 82 children aged 2 months to 12 years with first episode of UTI, not having any risk factor for UTI, and 64 healthy control children. The age, gender, weight, height, fever, vitamin $\mathrm{D}$ or calcium supplementation, urinalysis and urine culture were recorded.

Results The serum levels of 25(OH)D3 were significantly lower in the study group compared to healthy control group (11.69 \pm $3.25 \mathrm{ng} / \mathrm{mL}$ vs. $27.57 \pm 4.72 \mathrm{ng} / \mathrm{mL} ; \mathrm{p}<0.001)$. There was statistically significant difference in serum $25(\mathrm{OH}) \mathrm{D} 3$ levels between the patients with upper UTI compared to the patients with lower UTI $(8.63 \pm 2.76 \mathrm{ng} / \mathrm{mL}$ vs. $14.22 \pm 2.97 \mathrm{ng} / \mathrm{mL} ; \mathrm{p}<0.001)$. The serum levels of $25(\mathrm{OH}) \mathrm{D} 3$ were significantly lower in girls compared to the boys in the study group $(10.91 \pm 3.42 \mathrm{ng} / \mathrm{mL}$ vs. $13.20 \pm 4.38 \mathrm{ng} / \mathrm{mL} ; \mathrm{p}<0.001)$. Multivariate analysis showed that a serum $25(\mathrm{OH}) \mathrm{D} 3$ level of $<15 \mathrm{ng} / \mathrm{mL}$ (odds ratio 3.50 , 95\% confidence interval $1.62-7.57 ; \mathrm{p}=0.001$ ) was associated with UTI in children.

Conclusions Our results suggest that vitamin D deficiency is a risk factor for UTI in children and low serum level of vitamin D in girls is one of the reason for prone to UTI.

\section{Abstract PS-244a Table 1}

\begin{tabular}{|l|l|c|}
\hline Variable & OR $(95 \%$ Cl) & p value \\
\hline 25(OH)D3 of $<15 \mathrm{ng} / \mathrm{mL}$ & $3.503(1.621-7.571)$ & 0.001 \\
CRP $(\mathrm{mg} / \mathrm{dL})$ & $1.016(1.012-1.020)$ & 0.000 \\
WBC $(/ \mathrm{mm} 3)$ & $1.003(1.001-1.005)$ & 0.003 \\
\hline
\end{tabular}

\section{Neurodisability}

\section{PS-245 IS EARLY DETECTION OF ATTENTION PROBLEMS IN PRETERM CHILDREN POSSIBLE? THE VALUE OF NEUROPSYCHOLOGICAL ASSESSMENT AT PRESCHOOL AGE}

${ }^{1} \mathrm{~V}$ Giordano, ${ }^{2} \mathrm{U}$ Leiss, ${ }^{3} \mathrm{~S}$ Brandstetter, ${ }^{3} \mathrm{M}$ Hayde, ${ }^{3} \mathrm{~K}$ Klebermass-Schrehof, ${ }^{3} \mathrm{R}$ Fuiko, ${ }^{2} \mathrm{~L}$ Weiler. ${ }^{1}$ Department of Pediatrics and Adolescent Medicine. Division of Neonatology Pediatric Intensive Care and Neuropediatrics, Medical University of Vienna, Vienna, Austria; ${ }^{2}$ Department of General Pediatrics Division of Neuro-Oncology, Medical University of Vienna, Vienna, Austria; ${ }^{3}$ Department of Pediatrics and Adolescent Medicine Division of Neonatology Pediatric Intensive Care and Neuropediatric, Medical University of Vienna, Vienna, Austria

\subsection{6/archdischild-2014-307384.544}

Background Advances in neonatal intensive care have improved the survival rate of preterm babies. However, despite the increased survival rate of these babies, the risk for cognitive and behavioural problems at school age has increased. These problems are often attributable to specific attentional deficits. The early detection of attentional problems is therefore a challenging but important endeavour for clinicians.

Objective The investigation of attentional functioning in all its subcomponents in preterms children at preschool age.

Methods Preterm $(\mathrm{N}=56)$ and full-term neonates $(\mathrm{N}=56)$ between 5;5 and 6;11 years (average 5;7), matched for age, were assessed for the following attentional components: alertness, sustained attention, processing speed, orienting, perception, focused attention, go/nogo, distractibility, divided attention and flexibility. Each construct was assessed through subtests of the following neuropsychological batteries: KITAP/TAP and HAWIK-IV. Further factors such as parental ratings and descriptive item-based evaluation of the child's behaviour during the neuropsychological assessment were also considered.

Result Preterms show poor attentional performance in sustained attention, focused attention and distractibility, as well as reduction of processing speed in a visual search task, divided attention and flexibility. Decrease of volitional attention compared to automatic attention was also identified. No problems were detected in alertness and inhibition (go/nogo). Additionally, a higher rate of test-aborts, decreased motivation, and poor parental ratings were detected among the preterm population.

Conclusion The neuropsychological results highlight the difference of attentional functioning between preterm and full-term neonates and permit an early detection of attention deficits.

\section{PS-246 SELF-REPORTED QUALITY OF LIFE AT 19-23 YEARS AND CORRELATIONS WITH MOTOR SKILLS IN YOUNG VLBW ADULTS WITHOUT CEREBRAL PALSY}

${ }^{1}$ KAl Evensen, ${ }^{2} \mathrm{MM}$ Husby, ${ }^{2} \mathrm{MS}$ Indredavik, ${ }^{2} \mathrm{AM}$ Brubakk, ${ }^{2} \mathrm{~J}$ Skranes. ${ }^{1}$ Public Health and General Practice, Norwegian University of Science and Technology, Trondheim, Norway; ${ }^{2}$ Laboratory Medicine Children's and Women's Health, Norwegian University of Science and Technology, Trondheim, Norway

\subsection{6/archdischild-2014-307384.545}

Objective To study changes in self-reported quality of life (QoL) in very low birth weight (VLBW: $\leq 1500 \mathrm{~g}$ ) young adults, and to examine correlations between QoL and motor skills in young adult age.

Design/methods A hospital-based follow-up study of 28 VLBW young adults without cerebral palsy and 29 term-born controls. 